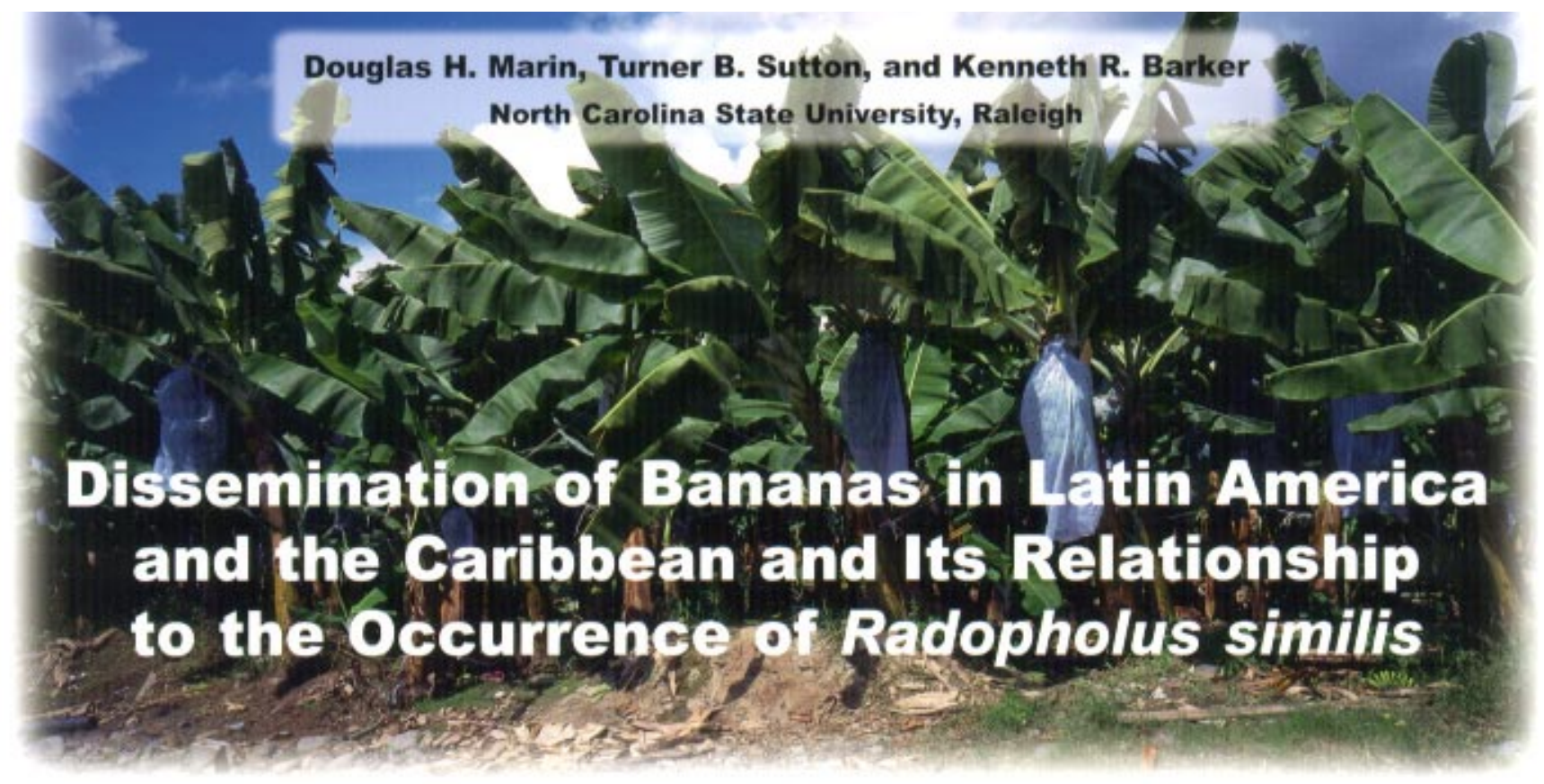

Bananas (Musa AAA) and plantains (Musa AAB) are important components of the human diet in almost every country of the world, either as a cooked food or fresh fruit. They are an excellent food source, and in some countries of the world (e.g., parts of Africa), they are the principal components of the diet. Bananas are a source of fiber, are low in sodium, and are the richest ready-to-eat source of vitamin B6 and potassium (7). They are the most widely consumed fresh fruit in the United States and are found year-round in supermarkets from the largest city to the smallest town. The average American citizen eats more than $10 \mathrm{~kg}$ of bananas yearly (24).

Over 76 million metric tons of bananas and plantains are produced worldwide each year, accounting for over 1.5 million jobs (43). Approximately $15 \%$ of bananas and plantains are grown for export. Exports are extremely important to the economies of many developing countries. For example, in Costa Rica, banana exports account for over one-half billion dollars (U.S.) in revenue, which is second only to tourism as a source of income.

Cultivated bananas are much improved over the "wild" progenitors that originated in Southeast Asia. Not only have bananas been improved by human intervention, but the crop has been spread by humans throughout the tropical growing regions of the world. As with many plant species moved by people, parasites and pathogens of bananas were moved along with them. Among the most important of these banana pathogens is the burrowing nematode, Radopholus similis (Cobb) Thorne.

Dr. Marin's address is: CORBANA, P.O. Box 65041000, San José, Costa Rica; E-mail: dmarin@ corbana.com

Publication no. D-1998-0706-01F

(C) 1998 The American Phytopathological Society

\begin{tabular}{|c|c|c|c|c|}
\hline Genus & Genome $^{\mathbf{a}}$ & Type & Subgroup & Common cultivars \\
\hline Musa & AAA & Bananas & $\begin{array}{l}\text { Gros Michel } \\
\text { Cavendish }\end{array}$ & $\begin{array}{l}\text { Gros Michel } \\
\text { Cocos } \\
\text { Lacatan } \\
\text { Dwarf Cavendish } \\
\text { Valery (Robusta, Poyo) } \\
\text { Grande Naine }\end{array}$ \\
\hline Musa & $\mathrm{AAB}$ & Plantain & Plantain & $\begin{array}{l}\text { False Horn } \\
\text { French }\end{array}$ \\
\hline Musa & $\mathrm{ABB}$ & Cooking bananas & Maia Maoli & $\begin{array}{l}\text { Maqueño } \\
\text { Bluggoe } \\
\text { Pelipita }\end{array}$ \\
\hline
\end{tabular}

a The designations A and $\mathrm{B}$ in the genome correspond to Musa acuminata and M. balbisiana, respectively. Bananas are natural hybrids of these two Musa species.

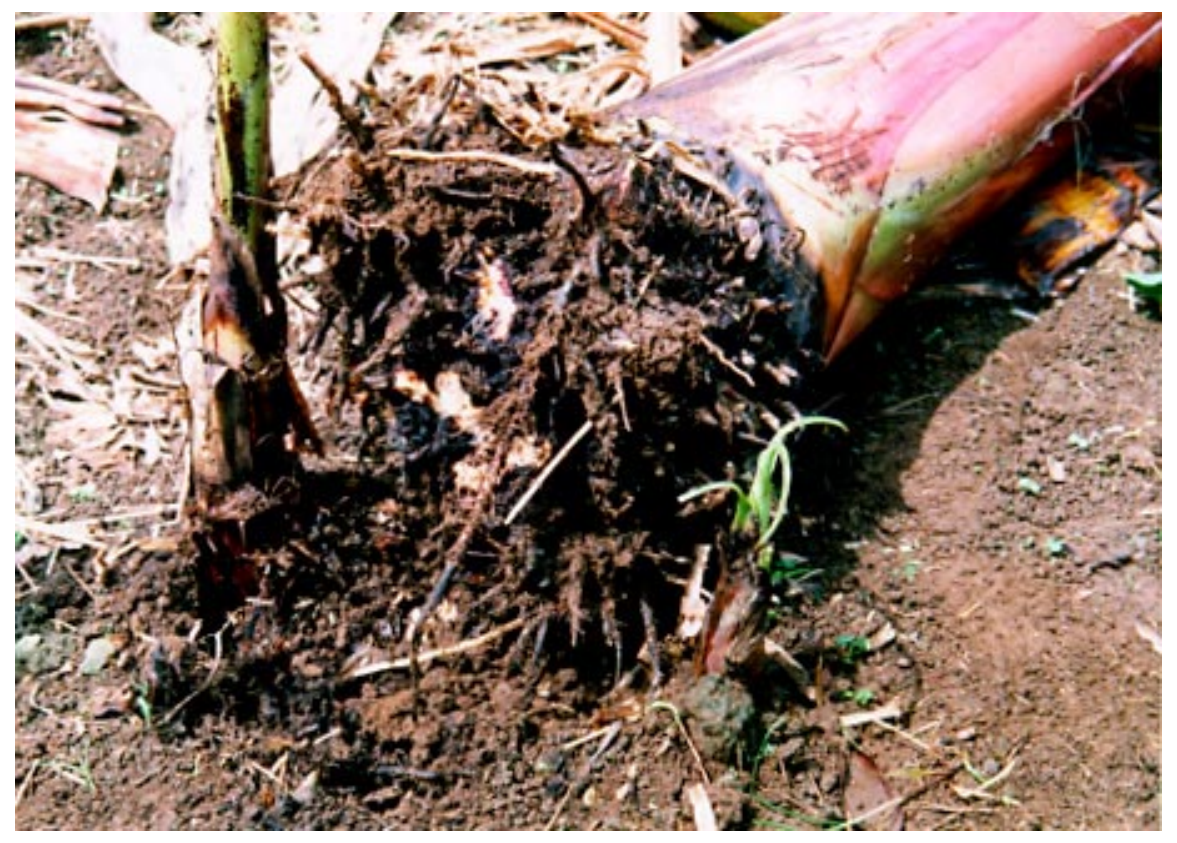

Fig. 1. Uprooting of banana plant with severe damage primarily caused by Radopholus similis. 

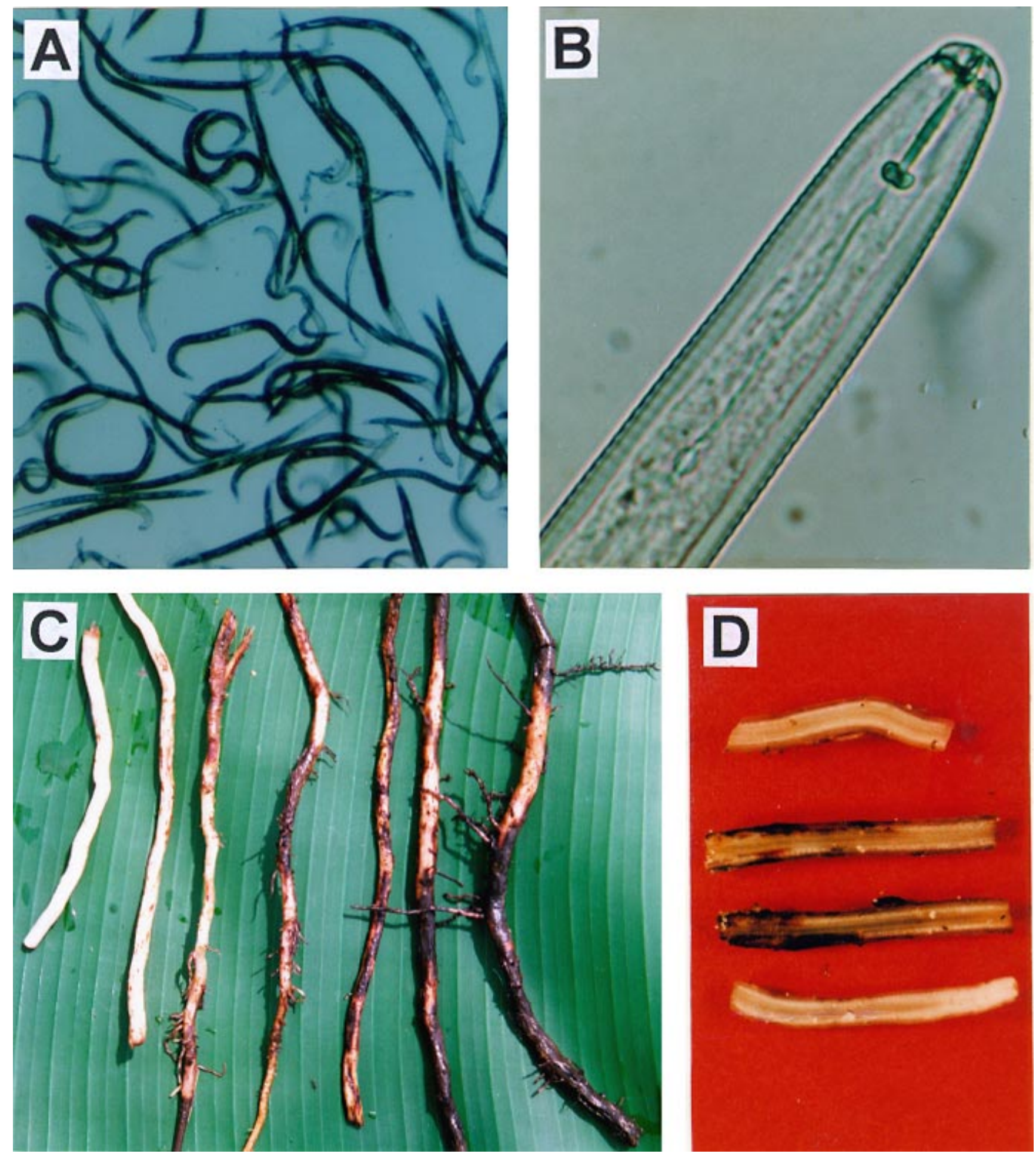

Fig. 2. (A) Radopholus similis from carrot-disk culture. (B) Female showing stylet. (C) Banana roots showing nematode damage. Blackened areas are the result of the invasion of secondary fungi and bacteria. (D) Longitudinal section of a banana root showing discoloration of cortical tissue parallel to the stele.

We suggest, based on the evidence from the literature, that the dispersal of $R$. similis in the banana-production regions in Latin America and the Caribbean region occurred at least at three different times during the establishment of bananas in those regions. The first introduction probably occurred in the mid-1830s with the banana cultivar Gros Michel, the second in the 1950s with Cocos, a dwarf mutant of
Gros Michel, and the third and most important with Cavendish cultivars in the 1960s. Additionally, the nematode could have been dispersed with other Musa spp. and ornamentals $(36,37,69)$ to the bananagrowing areas.

\section{Origin of Bananas}

The plant named "banana" includes a large number of parthenocarpic clones belonging to the genus Musa of the family Musaceae $(47,68)$. The center of origin of the wild banana is Southeast Asia and the Pacific Islands extending from India to Papua New Guinea and including Malaysia and Indonesia $(12,45,55,58)$.

Edibility evolved first in wild Musa acuminata. Taxonomic evidence indicates that the primary center where edibility evolved was the Malay Peninsula, possibly 
including closely neighboring territories (56). Most cultivated bananas are derived from the species $M$. acuminata (genome A) and Musa balbisiana (genome B). Simmonds and Shepherd (57) designed a method of indicating the relative contribution of the two species to the different cultivated genotypes using the A and B genome designations (Table 1). Most of the commercial cultivars are triploids and belong to the AAA group. The three major groups under cultivation worldwide are: AAA, AAB, and ABB (56). Relatively few banana clones have moved from the center of origin in Southeast Asia, with the result that diversity of these plants declines from Asia to Africa to America (56).

\section{Banana-Host of Many Nematode Species}

Plant-parasitic nematodes are widespread and are the most damaging pests of bananas. Over 100 species have been reported on banana and plantain $(8,20)$. Those nematode species involved in the destruction of the primary roots are the most detrimental to the crop. The disruption of the anchorage system results in uprooting and toppling of the plants (Fig.
1 ; 20) and associated losses average approximately $20 \%$ per year (51).

Bananas, as most tropical crops, are characterized by polyspecific nematode parasitism. The burrowing nematode is widespread and is the most damaging species attacking most bananas, plantains, and cooking bananas $(18,20,60)$. However, other nematode genera can be present in the same root system. Lesion (Pratylenchus spp.), spiral (Helicotylenchus spp.), and root-knot nematodes (Meloidogyne spp.) are usually associated with the crop. In spite of their importance in some areas, most research has focused on the burrowing nematode. Few studies have dealt with the interaction between nematodes in banana roots, probably due to the dominance of the burrowing nematode over the other species $(18,20)$.

Damage caused by lesion nematodes is probably underestimated because of the similarity of the necrosis of root and corm to that caused by the burrowing nematode. Pratylenchus goodeyi is the most widespread and serious nematode in the African highlands and the major pest of Cavendish bananas in the Canary Islands. Banana is the only known host. Pratylenchus coffeae is distributed throughout the tropics and has many hosts. In South and Central America, it appears to be more often associated with plantain than the Cavendish clones $(17,19)$, but there is no evidence to suggest that any musaceous plant is a preferred host (19).

The spiral nematode, Helicotylenchus multicinctus, occurs in most regions where bananas are grown $(18,38)$. In tropical areas where $R$. similis is present, the spiral nematode is of secondary importance (38). However, $H$. multicinctus may be numerically dominant to $R$. similis in localities where the species coexist (18). In subtropical areas where the burrowing nematode is rare or absent, $H$. multicinctus may be the major nematode problem of the crop. Severe decline of bananas caused by $\mathrm{H}$. multicinctus occurs in Argentina, Cuba, Cyprus, Florida, Israel, Lebanon, and South Africa (38).

All banana cultivars are hosts of the root-knot nematodes (Meloidogyne spp.), which can cause considerable deformation and stunting of the roots. However, because they do not cause plants to topple, these nematodes are not thought to be as important as the more destructive lesionforming species (17), which in mixed population are generally dominant $(11,17)$.

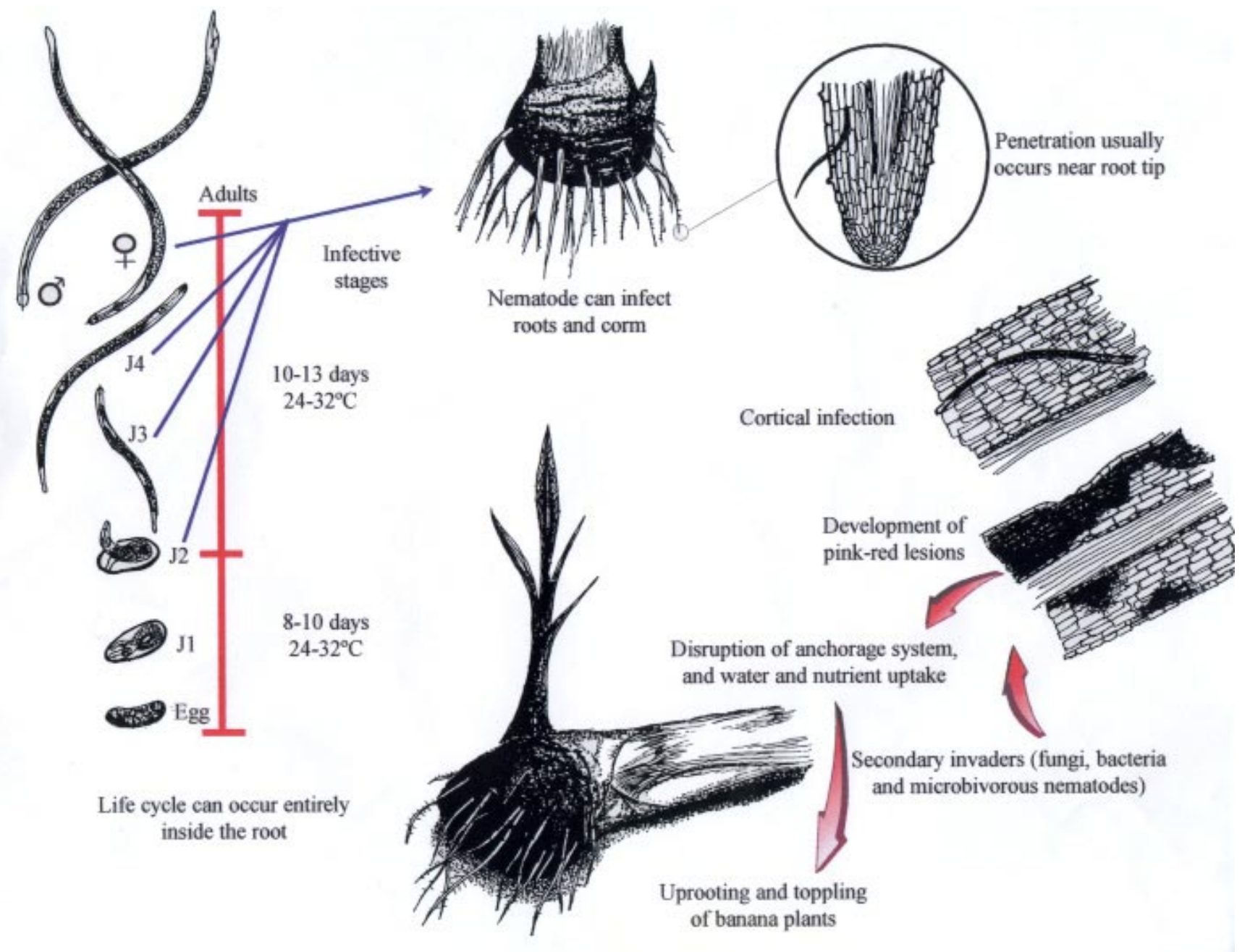

Fig. 3. Life cycle of Radopholus similis. 
Nevertheless, this situation is cultivardependent, and consequently, root-knot nematodes may dominate over the burrowing nematode (11). Meloidogyne spp. populations are probably suppressed by high populations of $R$. similis and $H$. multicinctus, which cause extensive root destruction (18). Root-knot nematodes are a problem in Taiwan, where they are the major nematode pest, and in some localities new to bananas where introduction of $R$. similis and Pratylenchus spp. has been avoided (17).

\section{The Burrowing Nematode}

$R$. similis was first described by Cobb (10) in 1891 from banana roots from Fiji $(10,20)$. He described the new species in 1893 as Tylenchus similis $(9,10,33,40,61)$ and indicated that females were not observed. In 1907, Cobb found both sexes infecting roots of sugar-cane in the Hawaiian Islands $(9,10,33,40,61)$. Several years later, he received infected corms of Gros Michel from Jamaica and found additional specimens, which he used to publish a more complete description of the species in 1915 (10,33,60). Since then, $R$. similis has been found in most bananagrowing areas worldwide (Fig. 2; 20). However, $R$. similis apparently is still absent in many banana-production countries, including Israel, the Canary Islands, Cape Verde Islands, Cyprus, Crete, Mauritius, the highlands of East Africa, and Taiwan $(18,20)$. Most other species belonging to the genus Radopholus have been described from Australia and New Zealand. For this reason, Radopholus is considered indigenous to that area $(34,53)$. A recent description of the distribution of $R$. similis is available (5).
$R$. similis is a migratory endoparasite that is able to complete its life cycle entirely within the root (Fig. 2A and B). Penetration occurs mostly near the root tip, but nematodes can migrate along the entire length of the root (Fig. 2C). Females and all juvenile stages are infective, although males lack stylets and are probably nonparasitic (20). $R$. similis invades, feeds, and reproduces in cells of the cortex of the roots and corm $(2,3,17,33)$. The nematode burrows between cortical cells, punctures cell walls with its stylet, and feeds on the cytoplasm, making cavities within the roots. As the cells are destroyed and the nematode migrates, cavities coalesce to form red-brown lesions (Fig. 2C; 2,3,37). Migration and egg-laying are governed by nutritional factors as females move away from the necrosis. Within the infected tissues, the females lay four to five eggs per day for 2 weeks. The eggs hatch after 8 to 10 days, and the juvenile stages are complete in 10 to 13 days (27); the life cycle is completed in 20 to 25 days at 24 to $32^{\circ} \mathrm{C}$. As the nematode colony grows and expands its feeding area, a pink-red coloration extends parallel to the plant stele through the width of the cortical tissue (Fig. 2D; 2,3,33). The characteristic pinkred areas are infested with all stages of the nematode, whereas the blackened tissues are a result of the invasion by secondary fungi and bacteria $(2,3,17,33)$. Microbivorous nematodes also become abundant in tissues, which are in the process of disintegration (33). The presence of fungi in nematode-induced lesions probably hastens the destruction of the roots and may contribute to toppling disease (Fig. 3; 20, $54,60)$.
Because bananas are traditionally propagated vegetatively by corms or parts of corms (often referred to as seeds), planting material is mainly responsible for widescale dissemination of the pest $(20,32,33)$. The dissemination of $R$. similis is considered relatively recent, probably starting at the beginning of the nineteenth century (20). The wide distribution of burrowing nematodes is often correlated with the import of banana corms of the subgroup Cavendish (20).

Two morphologically indistinguishable host races of $R$. similis were first described by DuCharme and Birchfield (13). One race was shown to parasitize bananas but not citrus, whereas other race infected citrus and bananas. The banana race has been identified in most bananagrowing areas of the world (Fig. 4), whereas the citrus race is known to occur only in Florida. Based on a number of biological, biochemical, and karyotype differences, the citrus race was elevated to a species level and renamed $R$. citrophilus (26). However, recent molecular and biological data indicate that $R$. similis and $R$. citrophilus may actually be the same species and therefore should be considered races of $R$. similis (29).

Recent molecular studies $(14,21,22,27$, 28,35 ) have revealed a high degree of genetic similarity among burrowing-nematode populations from different areas of the world. In a cluster analysis of random amplified polymorphic DNA profiles of mostly African $R$. similis populations, Fallas et al. (14) found two separate clusters; however, a geographical relationship was not clearly evident. They suggested that

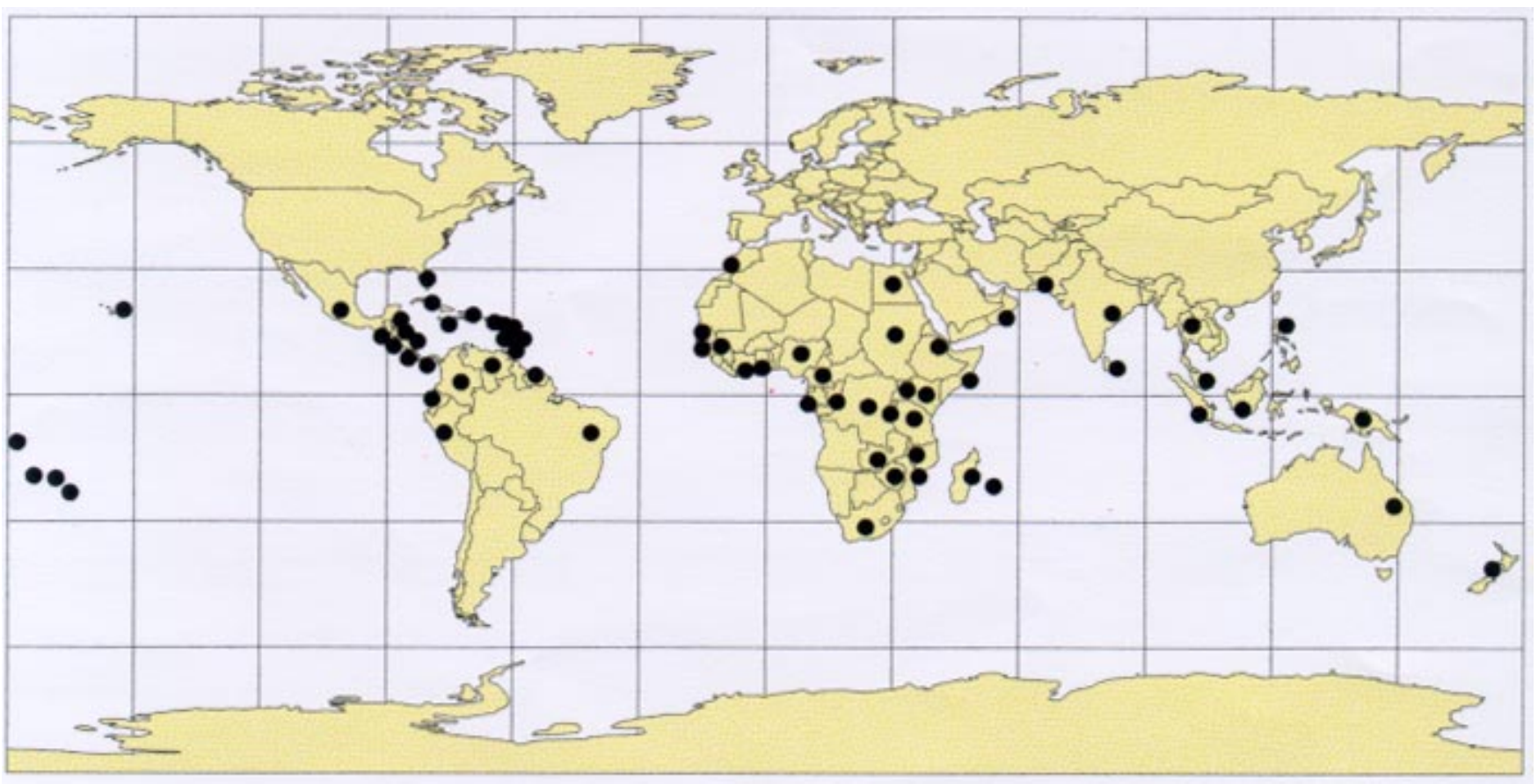

Fig. 4. Worldwide distribution of the burrowing nematode (Radopholus similis) associated with bananas $(\bullet=$ infected with $R$. similis). 
knowledge of the origin of the planting material could help explain the genetic similarity among burrowing nematode populations. In contrast, Marin (35) found that the genetic relationship among Central American and Caribbean populations seemed to be associated with their geographic distribution. Aggressiveness of burrowing nematodes, a relative measure of their general damage potential without regard to resistance genes (52), varies among populations from different areas of the world $(15,22,35,43,50)$; however, this character apparently does not correlate with the molecular similarity among these populations (35).

Although best known as a pest of Musa spp., Piper nigrum, Saccharum spp., and Citrus spp., $R$. similis also attacks many crops that are important in world commerce and subsistence agriculture, such as coffee and anthurium (39). Browning (6) suggested that pathogens of these and other crops did not evolve in agricultural systems but coevolved with them in natural ecosystems, a process which continues (6). The most important hosts for $R$. similis all share a common center of origin in the Indo-Malayan region (31). Vavilov (67) contended that parasites are more diverse in the center of origin of the hosts (cultivated and wild). Therefore, considering these factors $(6,67)$, it is very likely that $R$. similis is indigenous to the IndoMalayan area rather than to Australia, as has been suggested $(34,53)$. Razak (44) suggested that $R$. similis is indigenous to Malaysia. Pattison et al. (41) suggested that $R$. similis was introduced into Australia, probably with infected planting material from Fiji.

\section{Movement of Bananas to the New World}

No exact dates can be assigned to the evolution and dissemination of edible bananas (Fig. 5). The essential events in Southeast Asia probably occurred millennia rather than centuries ago (56). From about the fifth to the fifteenth centuries, and perhaps earlier, the Indian Ocean was navigated by traders from Saudi Arabia, Persia, India, and Indonesia. Banana cultivars from Southeast Asia were distributed over the coasts of the Indian Ocean $(12,45,62)$. The cultivars were a mixture of genomic combinations, including Red (AAA), Silk and Prata (AAB), Pisang Awak (ABB), and even AAs and $\mathrm{ABs}$ and some plantains (12).

Bananas and plantains were present in Africa before the arrival of the Portuguese in the fifteenth century. It is likely that they entered Africa from Indonesia-Malaysia, rather than from India, by way of Madagascar and/or the east coast around the tenth century $(23,45,46,56,62)$. However, the cultivars of the upland of East Africa and of low tropical Africa are broadly different $(30,56)$. It is believed that the sweet bananas (AA and AAAs) were introduced into East Africa very early from Arab settlements (30). Later, in or after the seventh century, cooking bananas (AAB and $\mathrm{ABBs}$ ) were introduced into Madagascar from southern Borneo. From there, they were moved northward through the Zambies Valley, and then westward along the Congo to the west coast (30). West Africa has mainly cooking bananas, although some small, sweet AA and AAA clones are grown. Mainly dessert bananas are present in East Africa, including Egypt (30).
The Portuguese first explored the coast of Guinea from 1469 to 1474 and took bananas from there to the Canary Islands in the late fifteenth century $(23,30,45,47,62)$. However, exactly when bananas reached the Canary Islands is still unclear and somewhat controversial (25). Simmonds (56) and Hernández (25) provided evidence that they arrived in Gran Canaria in the year 1402, whereas Rodríguez (47), Hernández (25), and Langdon (30) reported 1482. Because the Portuguese first explored the coast of Guinea in 1469 to 1474 , it is likely that bananas were introduced late in the 1400s rather than earlier in that century as stated by Simmonds (56) and Hernández (25). Hernández (25) also considered the possibility that bananas came from the Philippines, which were under Spanish dominion.

In 1516, Friar Tomás de Berlanga brought a banana plant to Hispaniola, currently Dominican Republic, from the $\mathrm{Ca}$ nary Islands $(16,30,45,47,55,62,68)$. It has also been suggested that bananas were introduced by the Portuguese into the New World via the Cape Verde Islands $(1,4,66)$. Simmonds (55) stated that the clone brought by de Berlanga was unidentified. However, Langdon (30) claimed that the banana introduced by Father de Berlanga was known as "Dominicos," which today is a common name for a plantain belonging to the French group. The first clones identified in the New World were the "silk fig" (Apple Banana, Musa AAB) and the French plantain (Musa AAB), which were present in the West Indies in the seventeenth century (55).

Father de Berlanga also planted bananas in the Monastery of San Francisco, where

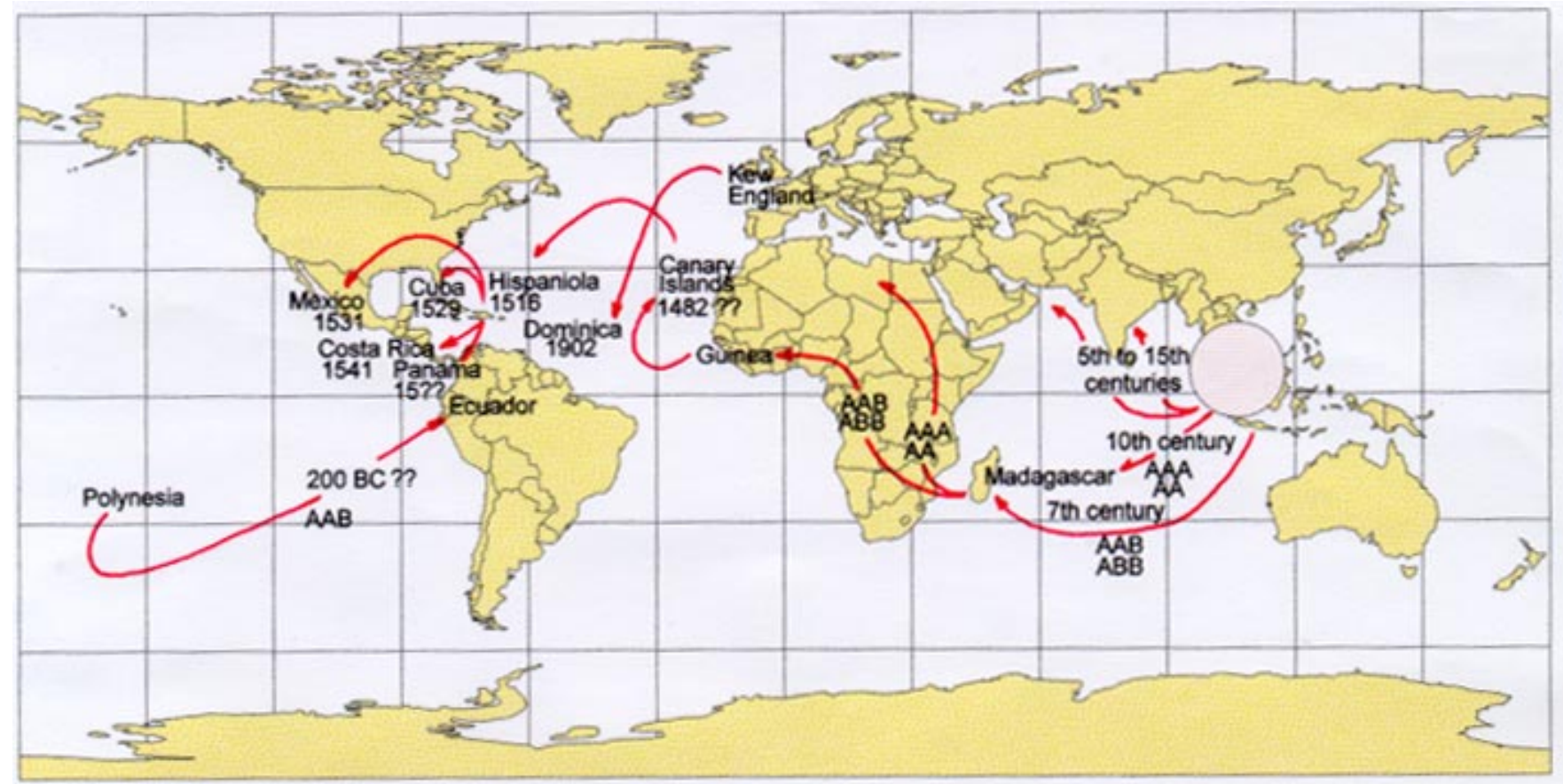

Fig. 5. Spread of bananas from the Indo-Malay region to the rest of the world. 
they flourished (47). Then they were taken to Cuba in 1529 , to Mexico in 1531 by Vasco de Tueraoa, and to Costa Rica in 1541 by Diego Guadierrez. When Father de Berlanga was made bishop of Panama, he also took banana plants with him (47).

Although hypothesized, there is little evidence of pre-Columbian presence of bananas in the New World $(56,68)$. This hypothesis is based on the findings of leaves resembling those of bananas in preColombian deposits in South America. However, these leaves may belong to another plant closely resembling the banana plant (68). There also are reports from studies in pre-Columbian graves in Peru of finding not only banana leaves but also seedless banana fruit that belonged to the old species Musa paradisiaca, today known as the plantain group (Musa AAB) $(1,66)$. According to Fernandez de Oviedo (16; originally published in 1535 to 1537 ), bananas were not known in the New World before 1516, at which time they were brought to Santo Domingo by Father de Berlanga.

In contrast, Langdon (30) assembled evidence that bananas were "fruits of the land," meaning that they were already present when the Spaniards arrived. He presented evidence of banana plants in Puerto Rico, Mexico, Costa Rica, Panama, Colombia, the Guianas, Brazil, Ecuador, and Peru, from 1535 to 1556 . He suggested that bananas have been a major food crop in both Polynesia and tropical South America for more than 2,000 years and provided evidence for the link between the two regions (30). Von Loesecke (68) stated that the fruit probably was introduced from the Pacific by the first migrations of Polynesians about the time of Christ. Other researchers have concluded that bananas from the Maia Maoli group (popoulu type) could have been taken from the Pacific to Ecuador around 200 B.C. $(12,30)$.

When the Amazon was explored, just 24 years after the banana arrived in Hispaniola, bananas were found under cultivation along the river. Because it is unlikely that bananas could have been disseminated so quickly from Mexico to Brazil, on the Atlantic side of South America $(1,4,66)$, it has been hypothesized that these tropical plants were brought to the New World before Columbus by West Africans who shared their environment with these plants $(1,4,66)$.

From the sixteenth to the nineteenth century, the Portuguese and the Spaniards carried bananas all over tropical America. Dutch, British, French, and German traders also played a role in the distribution of the Gros Michel and the Cavendish group to West Africa, Latin America, and the Caribbean (12). Gros Michel and Dwarf Cavendish were introduced early in the nineteenth century, and several other clones were introduced to Dominica via Kew Botanical Garden in 1902 (55).

Although bananas were introduced very early in the history of America, it is unlikely that $R$. similis was introduced at the same time. The fact that $R$. similis is absent in the Canary Islands (20) supports this hypothesis, because these islands were an important point of commerce for trade between America and the Old World.

\section{Introduction of Gros Michel (Musa AAA)}

Gros Michel appears to be native in Burma (currently Myanmar), Thailand, Malaysia, Indonesia, and Ceylon (currently Sri Lanka), but it is absent from or was recently introduced to the Philippines, New Guinea and the Pacific, Africa, and the New World. In the New World, Gros Michel first appeared in Martinique (Fig. 6) early in the nineteenth century $(45,47,55)$. Kervegant (1935), cited by Simmonds (55), suggested that a naval officer introduced it to the botanical garden at St. Pierre.

Although the exact date is unknown, the banana industry became established after the introduction of Gros Michel to Jamaica around 1835 from Martinique by Jean Francois Pouyat $(45,47,55,62)$. Forty years later, Gros Michel was distributed widely in Central America and the Caribbean area, and adopted for the banana trades (55).

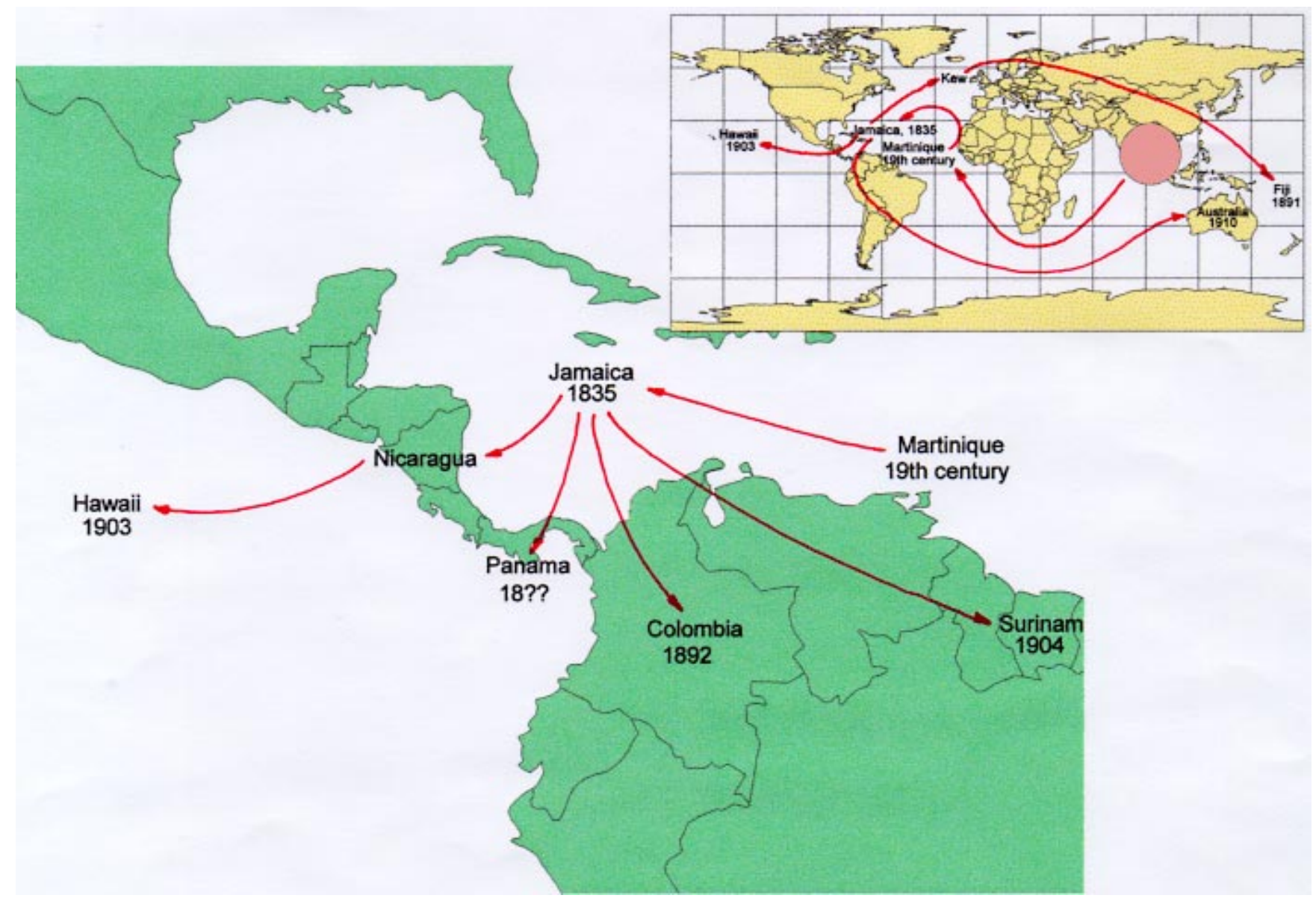

Fig. 6. Introduction of banana cv. Gros Michel from Southeast Asia. 
Commercial plantations in Central America and Cuba are believed to originate from the plant brought to Jamaica (45).

Colombia made the first import of Gros Michel banana suckers from Jamaica in 1892, and Surinam made the first import in 1904 (47). Gros Michel was grown almost exclusively in Almirante, Panama. Infections of banana by $R$. similis apparently were widespread, and uprooting was abundant. However, the symptoms associated with $R$. similis infection of Gros Michel and Cocos banana roots and corms were not described until 1957 (33).

Introductions of Gros Michel to the Pacific Islands were made around the turn of the century: from Jamaica to Fiji in 1891 (via Kew, England), to Hawaii in 1903 (via Nicaragua), and to Australia in 1910 $(43,50)$. There is no information about the introduction of Gros Michel to Fiji, previous to the introduction made from Jamaica, about the time Cobb made his observations on $T$. similis. Although no cultivar was

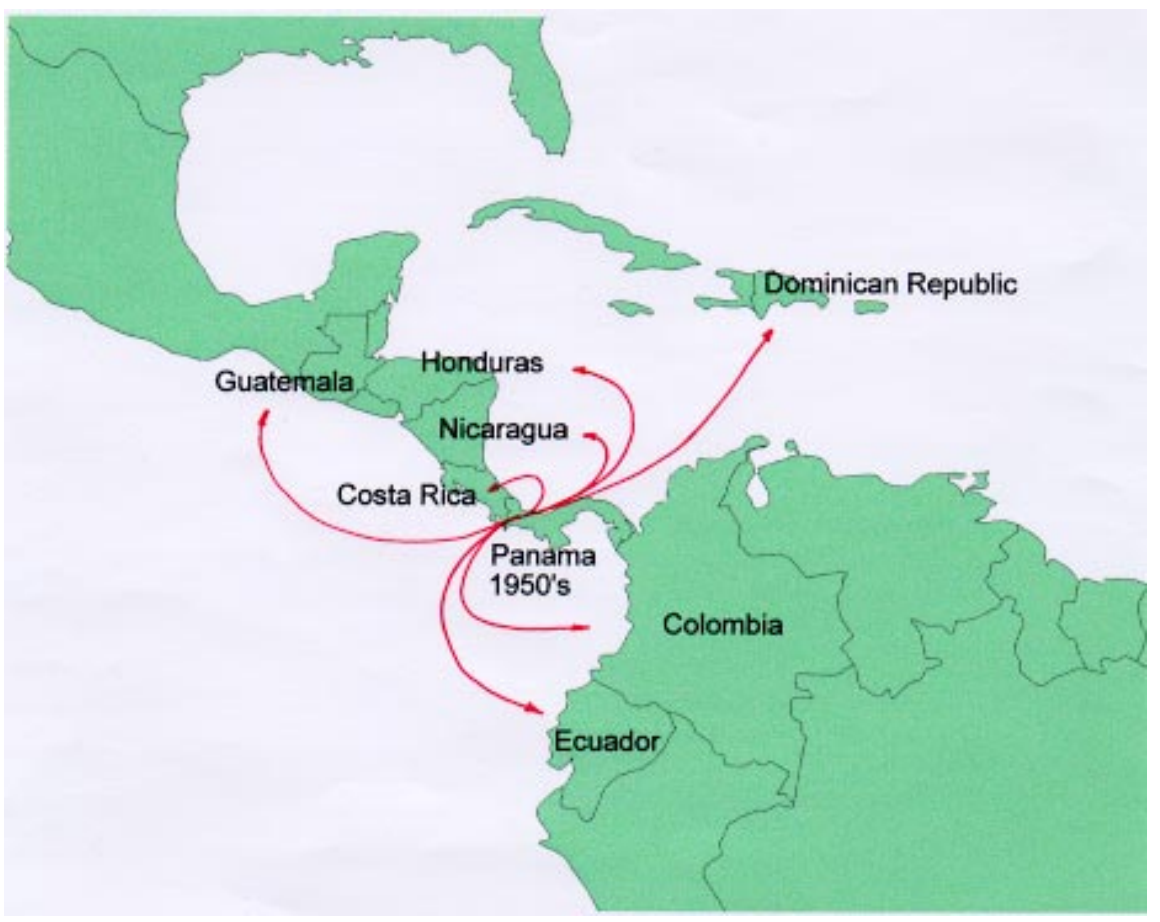

Fig. 7. Distribution of banana cv. Cocos in Central and South America.

mentioned during Cobb's visit to Fiji in 1890 to 1891 , it is possible that the first specimens of $T$. similis observed were associated with Gros Michel plants imported from Jamaica.

The introduction of $R$. similis to the New World probably occurred with the introduction of Gros Michel. The Gros Michel group has a moderate level of resistance to burrowing nematodes (49), which may have allowed this pest to go almost unnoticed at that time. Initial nematode screenings in Central America found that $R$. similis was present on Gros Michel $(33,63)$. Additionally, Cobb received infected Gros Michel corms from Jamaica to complete his description of $T$. similis in $1915(10,61)$.

\section{Introduction of Cocos (Musa AAA)}

The history of the Central American banana industry is largely the history of the United Fruit Company (55,58). Before 1958 , nematodes were of no concern to the banana industry. Banana growers traditionally cultivated Gros Michel, which resisted the damaging effects of nematodes. In the mid 1950s, a mutant of Gros Michel, known as Cocos, was distributed to all United Fruit Co. plantations (Fig. 7; Guatemala, Honduras, Costa Rica, Panama, Dominican Republic, and Turbo, Colombia, and possibly to Nicaragua and Ecuador). The Cocos cultivar was found in Finca Cocos in Puerto Armuelles, Panama. Because Cocos was more wind-resistant than Gros Michel, it became the latter's replacement. Unfortunately, seedbeds in Puerto Armuelles were contaminated with $R$. similis, and hundreds of thousands of infected seeds were distributed throughout

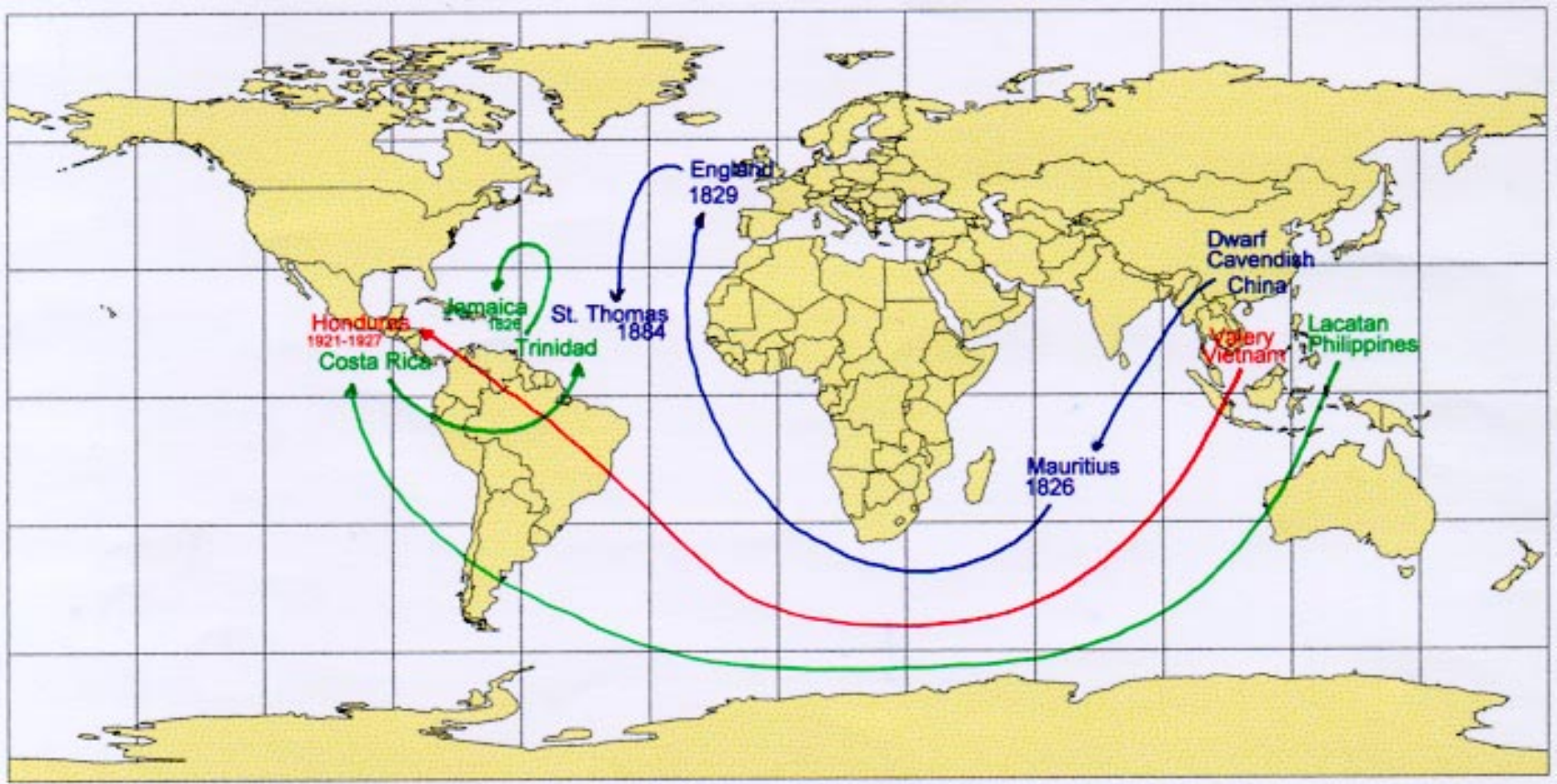

Fig. 8. Dissemination of the banana Cavendish cultivars from Southeast Asia to the rest of the world. 
the plantations of United Fruit Co. (52; C. Stephens, personal communication).

Cocos Farm, the site where the original Cocos plant was found in Armuelles in 1948, was sampled in 1958 , and no $R$. similis infestation was detected (63). From Cocos Farm, the cultivar was moved to Palo Blanco and from there to Zapatera and Jobo Farm. The site in Zapatera was probably the origin of the infestation of Cocos in Armuelles. The Gros Michel growing in those areas was also infected with this nematode (63). Cocos was introduced to Honduras from Armuelles in 1955. The seedbeds were established at Guaruma 2, and all plantings used as a seed source were infected (63).

The burrowing nematode was found in all divisions of the United Fruit Co. surveyed in the late 1950s (63). With exception of Tiquisate (Guatemala) and Esquinas (Costa Rica) districts, the occurrence was limited to the Cocos cultivar. So this pathogen apparently was transported along with the planting stock of the Cocos cultivar. In Tiquisate and Esquinas, the nematode was also found in Gros Michel (63). Thus, the second dissemination of $R$. similis occurred with the spread of Cocos. The source of contamination was, very likely, a Gros Michel plant.

\section{Dissemination of Abaca (Musa textilis) and Ornamentals}

A collection of abaca, also known as Manila hemp, also was brought to the Botanical Garden in Lancetilla, Honduras, from Panama in 1928 (48). However, the original source of abaca planting material is not documented. The establishment of abaca plantations in Central America during 1941 and 1942 was done with plant material from Lancetilla (48). If abaca was infected with $R$. similis during the seed reproduction at Lancetilla, it is likely that planting of this Musa sp. also contributed to the dissemination of the burrowing nematode in Central America. However, there is no documented evidence to support this hypothesis.

$R$. similis have been introduced to other regions with different host plants, such as ornamentals $(36,69)$, including species belonging to the genus Musa (69). Therefore, it is also possible that burrowing nematodes were introduced to bananagrowing areas with ornamental plants.

\section{Dissemination of Cavendish Cultivars (Musa AAA)}

The first and best known introduction of dwarf Cavendish (Chinese banana) was made by Charles Telfair from southern China to Mauritius in 1826 (Fig. 8). In 1829 , some plants were sent to Barclay of Burryhill in England. Later the Duke of Devonshire purchased one plant for his private gardens at Chatsworth. From there, the missionary John Williams took suckers to Samoa in 1838, and then the clone was spread to Tonga and Fiji in the 1840s, and from Tahiti to Hawaii about 1855. Austra-
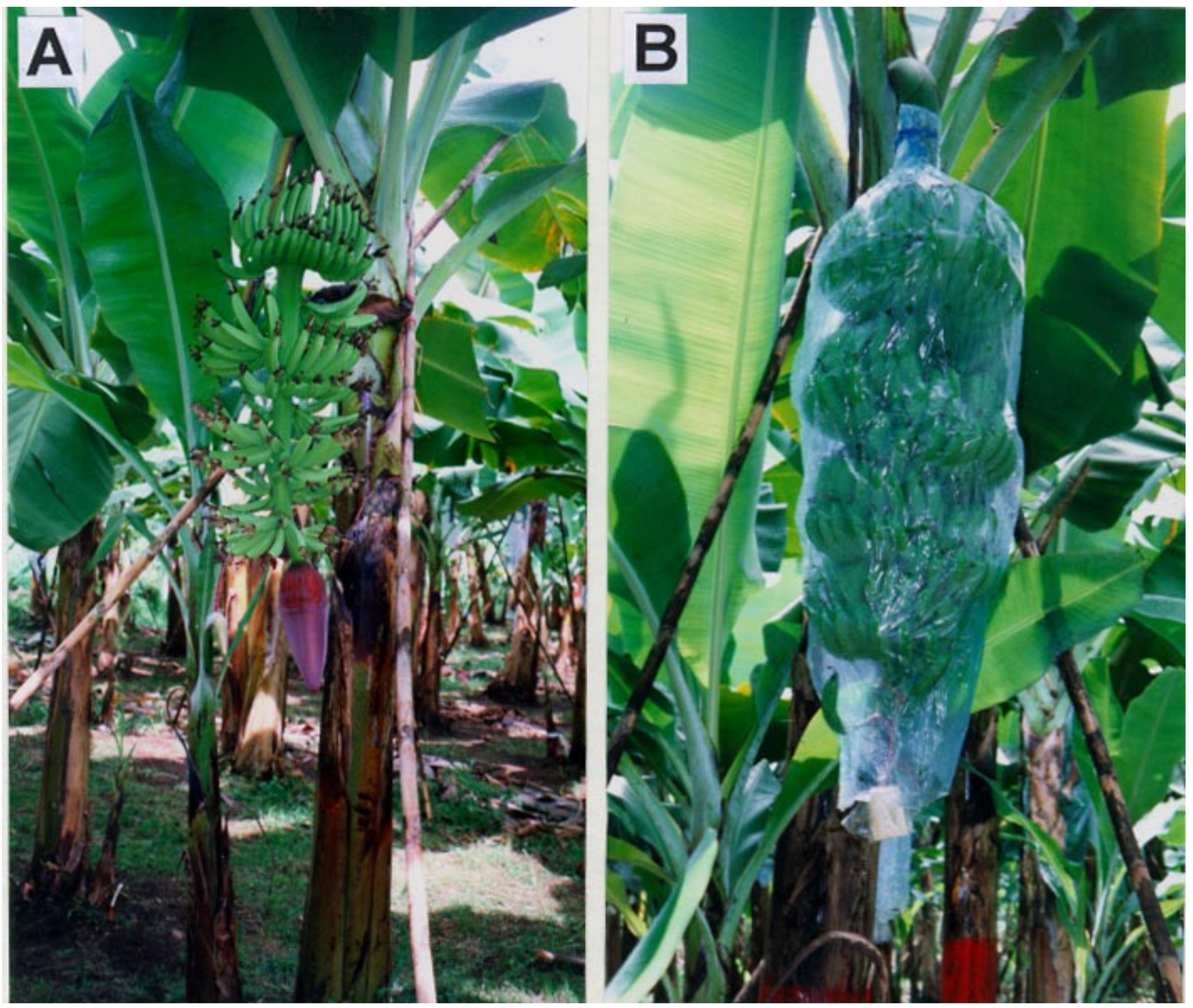

Fig. 9. (A) Young fruit and floral bud of banana cv. Grande Naine. (B) Bagged fruit of Grande Naine prior to harvest. 
lia and New Guinea probably received this clone from the same source $(43,45,55)$.

In 1884, dwarf Cavendish was imported and planted in Bath Gardens, St. Thomas. In 1909, the Robusta cultivar, also known as Valery, was brought into Jamaica from Guatemala and was planted in South Manchester (47,55). However, how Robusta reached Guatemala is not documented.

Lacatan, another Cavendish cultivar, was already grown in the Imperial College in Trinidad in 1933. The stock plants were obtained from the Trinidad Department of Agriculture and apparently came from the Philippines (Fig. 8) via Costa Rica (5). Lacatan was introduced to Jamaica from Trinidad about 1926 (47).

Except for the Standard Fruit Company in La Estrella, Costa Rica, and the Aguan, Honduras, only the United Fruit Co. grew bananas in Central America before the 1960s (C. Stephens, personal communication). When United Fruit Co. converted to the Cavendish types because of their resistance to Panama disease in 1958 to 1959, a shipload of Lacatan corms, heavily infected with $R$. similis, was brought to Changuinola, Panama, from Jamaica. Much of Changuinola was planted with this infected material, and production decreased rapidly (33; C. Stephens, personal communication).

The United Fruit Co. had a small banana breeding program in Panama in the 1920s. The program was started from cultivars brought from Cuba, Panama, and Costa Rica. The amount of germplasm was augmented by material collected from 1921 to 1927 by D. A. Reinking from French Indochina, the Philippines, Malay States, Siam, Sumatra, Java, Celebes, New Guinea, Halmahera, Banda, Australia, Burma, and India. Later, the program was terminated, and the collection was transferred to Lancetilla, Honduras. A new cultivar, Valery, was brought by Reinking from the Botanical Garden of Saigon (Fig. 8). Valery, which is resistant to Fusarium wilt (Panama disease), replaced Gros Michel in all countries except Panama in 1960s. In the 1980s, Valery was replaced with a dwarf cultivar, Grande Naine $(48,49$; C. Stephens, personal communication), which is one of the most widely grown cultivars today (Fig. 9).

\section{Conclusion}

Gowen and Queneherve (20) stated that the widespread distribution of the burrowing nematode often is associated with areas where banana corms of the Cavendish subgroup were imported. The evidence provided in the present review does not refute that assumption. However, there are reasons to believe that the spread of $R$. similis commenced in Central America and the Caribbean islands in the early 1820 s when Gros Michel arrived in Martinique (55). It is very likely that Cavendish culti-

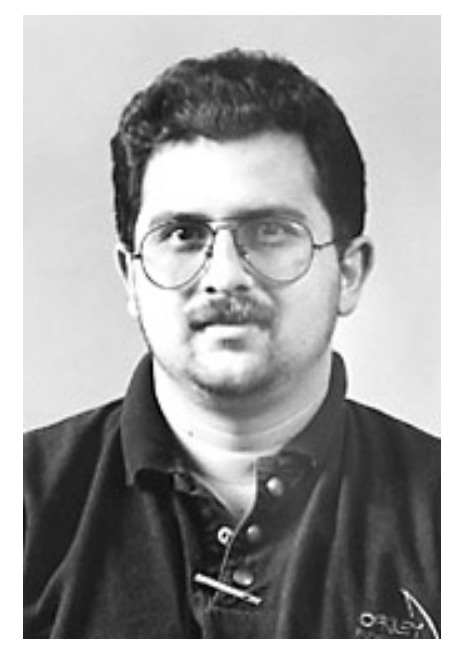

Douglas H. Marin

Dr. Marin is a nematologist (coordinator of the Nematology Section) of the Research Department of the National Banana Corporation of Costa Rica (CORBANA). He received his B.S. degree in plant science from the University of Costa Rica in 1987, his M.S. (1995) from the Department of Horticultural Science, and his Ph.D. (1997) from the Department of Plant Pathology at North Carolina State University. He served as a plant pathologist for CORBANA from 1988 until 1992. His research interests are epidemiology, genetic variability, and management of nematode problems, especially Radopholus similis, in bananas and other Musa cultivars.

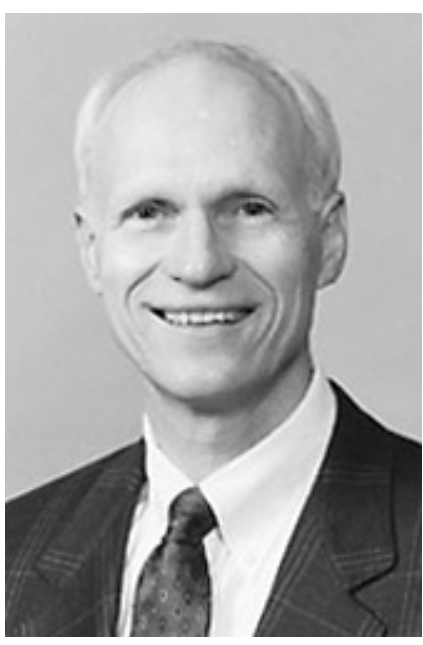

Turner B. Sutton

Dr. Sutton is a professor in the Department of Plant Pathology at North Carolina State University. He received his B.A. in botany and chemistry from the University of North Carolina and his M.S. and Ph.D. from North Carolina State University. After a post-doc at Michigan State University, he joined the faculty at NCSU in 1974 . He has a joint appointment in research, extension, and teaching. His research and extension activities have focused on the epidemiology, biology, and management of the summer diseases of apples. Through students from Costa Rica, he has worked on the epidemiology and control of black Sigatoka of bananas and characterization of the burrowing nematode. Dr. Sutton has taught an undergraduate level course in fruit disease management and currently teaches a graduate level course on the epidemiology and management of plant diseases.

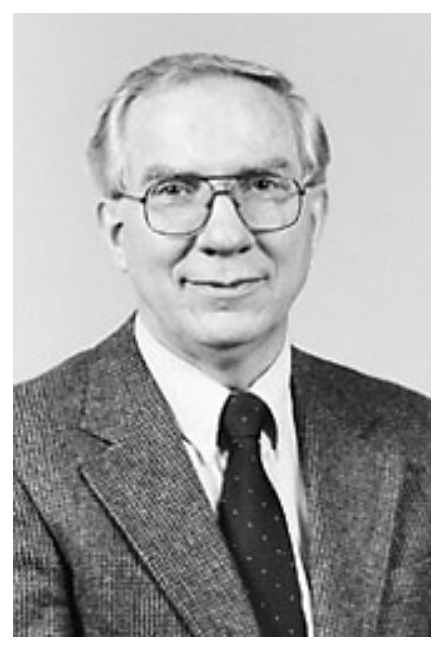

Kenneth R. Barker

Dr. Barker is a professor of plant pathology at North Carolina State University. He earned a B.S. degree in agronomy and an M.S. degree in plant pathology from North Carolina State University; his Ph.D. degree was earned at the University of Wisconsin. In addition to a major commitment to graduate education for more than three decades, he has an extensive research program on the ecology and management of plantparasitic nematodes. 
vars did not have any contact with burrowing nematodes until their arrival in the Americas. Because the Canary Islands and Mauritius apparently do not have Radopholus spp. infecting banana (20), and because this nematode has not been reported from China (70) or Vietnam (5), places from which Dwarf Cavendish and Valery were initially collected, $R$. similis must have contacted these cultivars elsewhere. Radopholus similis was not known in the Philippines, from which Lacatan was collected, before its introduction with infected Cavendish planting material in the 1960s (A. Salas, personal communication). The fact that the Cavendish cultivars, which are more susceptible than Gros Michel and Cocos to $R$. similis $(64,65)$, became important replacements of the latter cultivars (59) definitely contributed to widespread dispersal of the nematode in the bananagrowing countries.

The circumstantial evidence for a common origin of nematode populations in Central America and the Caribbean is strong. The highly conserved genome of this nematode $(14,21,27,28,35)$ can be explained from this perspective. With more precise knowledge of the distribution of the nematode in this area, it is possible to narrow even more the genetic relationship among populations. The reported variation in aggressiveness among populations of this parasite $(15,35,42,50)$, in spite of a high degree of genetic similarity among populations, is probably due to evolution of the populations under specific environmental conditions. This variation also could be influenced by the rapid changes in cultivars during the twentieth century.

\section{Acknowledgments}

We thank C. Stephens, A. Salas, J. A. Sandoval, and D. T. Kaplan for contributing useful information to this work, and H. Vilchez for providing some photographs and drawing the Radopholus life cycle.

\section{Literature Cited}

1. Ashe, G., Heyerdahl, T., Ingstad, H., Luce, J. V., Meggers, B. J., and Wallace, B. L. 1971. The Quest for America. Praeger Publishers, New York. pp. 135-137.

2. Blake, C. D. 1961. Root rot of bananas caused by Radopholus similis (Cobb) and its control in New South Wales. Nematologica 6:295310.

3. Blake, C. D. 1966. The histological changes in banana roots caused by Radopholus similis and Helicotylenchus multicinctus. Nematologica 12:129-137.

4. Bradley, M. 1992. Dawn Voyage: The Black African Discovery of America. A \& B Books Publishers, New York. pp. 138-139.

5. Bridge, J. 1993. Worldwide distribution of the major nematode parasites of bananas and plantains. Pages 185-198 in: Biological and Integrated Control of Highland Banana and Plantain Pests and Diseases. C. S. Gold and B. Gemmill, eds. IITA, Nigeria.

6. Browning, J. A. 1980. Genetic protective mechanisms of plant-pathogen populations: Their coevolution and use in breeding for resistance. Pages 52-75 in: Biology and Breeding for Resistance to Arthropods and Patho- gens in Agricultural Plants. Texas Agric. Exp. Stn., Misc. Publ. 1451.

7. Chandler, S. 1995. The nutritional value of bananas. Page 468-480 in: S. Gowan, ed. Bananas and Plantains. Chapman \& Hall, London.

8. Charles, J. S. K. 1998. Nematode pests of banana. Pages 288-309 in: Nematode Diseases in Plants. P. C. Trivedi, ed. CBS Publishers and Distributors, New Delhi, India.

9. Christie, J. R. 1959. Plant Nematodes: Their Bionomics and Control. Agricultural Experiment Station, University of Florida, Gainesville. pp. 96-113.

10. Cobb, N. A. 1915. Tylenchus similis, the cause of a root disease of sugar cane and bananas. J. Agric. Res. 4:561-568.

11. Davide, R. G. 1980. Influence of cultivar, age, soil texture, and $\mathrm{pH}$ on Meloidogyne incognita and Radopholus similis on banana. Plant Dis. 64:571-573.

12. De Langhe, E. 1996. Banana and plantain: The earliest fruit crops? Pages 6-8 in: INIBAP Annual Report 1995. INIBAP, Montpellier, France.

13. DuCharme, E. P., and Birchfield, W. 1956. Physiologic races of the burrowing nematode. Phytopathology 46:615-616.

14. Fallas, G., Hahn, M. L., Fargette, M., Burrows, P. R., and Sarah, J. L. 1996. Molecular and biochemical diversity among isolates of Radopholus spp. from different areas of the world. J. Nematol. 28:422-430.

15. Fallas, G., Sarah, J. L., and Fargette, M. 1995. Reproductive fitness and pathogenicity of eight Radopholus similis isolates on banana plants (Musa AAA cv. Poyo). Nematropica 25:135-141.

16. Fernández de Oviedo y Valdéz, G. 1959. Historia General y Natural de las Indias. Estudio preliminar de Juan Pérez Tudela. Vol. I. Libro IX. Cap. I. pp. 247-250.

17. Gowen, S. 1995. Pests. Pages 382-402 in: Bananas and Plantains. S. Gowen, ed. Chapman \& Hall, London.

18. Gowen, S. R. 1979. Some considerations of problems associated with the nematode pests of bananas. Nematropica 9:79-91.

19. Gowen, S. R. 1994. Burrowing nematode root rot (blackhead toppling disease). Page 21 in: Compendium of Tropical Fruit Diseases. R. C. Ploetz, G. A. Zentmyer, W. T. Nishijima, K. G. Rohrbach, and H. D. Ohr, eds. American Phytopathological Society, St. Paul, MN.

20. Gowen, S. R., and Queneherve, P. 1990. Nematode Parasites of Bananas, Plantains and Abaca. Pages 431-460 in: Plant Parasitic Nematodes in Subtropical and Tropical Agriculture. M. Luc, R. A. Sikora, and J. Bridge, eds. CAB International, Wallingford, Eng.

21. Hahn, M. L., Burrows, P. R., Gnanapragasam, N. C., Bridge, J., Vines, N. J., and Wright, D. J. 1994. Molecular diversity amongst $R a$ dopholus similis populations from Sri Lanka detected by RAPD analysis. Fundam. Appl. Nematol. 17:275-281.

22. Hahn, M. L., Burrows, P. R., and Wright, D. J. 1996. Genomic diversity between Radopholus similis populations from around the world detected by RAPD-PCR analysis. Nematologica 42:537-545.

23. Hall, R. L. 1991. Savoring Africa in the New World. Pages 161-171 in: Seeds of Change. H. J. Viola and C. Margolis, eds. Smithsonian Institution Press, Washington, DC.

24. Hallam, D. 1995. The world banana economy. Pages 509-533 in: Bananas and Plantains. S. Gowen, ed. Chapman \& Hall, London.

25. Hernández, G. 1991. Los plátanos. Impre Rapid, Barcelona. pp. 11-13.

26. Huettel, R. N., Dickson, D. W., and Kaplan, D. T. 1984. Radopholus citrophilus sp.n. Nematoda, a sibling species of Radopholus similis. Proc. Helminthol. Soc. Wash. 51:3235 .

27. Kaplan, D. T. 1994. Molecular characterization of the burrowing nematode sibling species, Radopholus citrophilus and $R$. similis. Pages 77-83 in: Advances in Molecular Plant Nematology. F. Lamberti, C. De Giorgi, and D. McK Bird, eds. Plenum Press, New York.

28. Kaplan, D. T., Vanderspool, M. C., Garret, C., Chang, S., and Opperman, C. H. 1996. Molecular polymorphisms associated with host range in the highly conserved genomes of burrowing nematodes, Radopholus spp. Mol. Plant-Microbe Interact. 9:32-38.

29. Kaplan, D. T., Vanderspool, M. C., and Opperman, C. H. 1997. Sequence tag site and host range assays demonstrate that Radopholus similis and $R$. citrophilus are not reproductively isolated. J. Nematol. 29:421-429.

30. Langdon, R. 1993. The banana as a key to early American and Polynesian history. J. Pacific Hist. 28:15-35

31. León, J. 1987. Botánica de los cultivos tropicales. 2da ed. IICA, San José, Costa Rica. pp. 91-92, 133-134, 238, 414

32. Loos, C. A. 1962. Studies on the life-history and habits of the burrowing nematode, $R a$ dopholus similis, the cause of black-head disease of bananas. Proc. Helminthol. Soc. Wash. 29:43-56.

33. Loos, C. A., and Loos, S. 1960. The blackhead disease of bananas (Musa acuminata) Proc. Helminthol. Soc. Wash. 27:189-193.

34. Luc, M. 1987. A reappraisal of Tylenchina (Nemata). 7. The family Pratylenchidae Thorne, 1949. Revue Nematol. 10:203-218.

35. Marin, D. H. 1997. Characterization and diversity of Radopholus similis populations on selective germplasm of bananas. Ph.D. diss. North Carolina State University, Raleigh.

36. Martin, K. J. 1978. Occurrence of Radopholus similis and other plant-parasitic nematodes in ornamental plants being transported into Arizona. Plant Dis. Rep. 62:293.

37. Mateille, T. 1994. Comparative host tissue reactions of Musa acuminata (AAA group) cvs Poyo and Gros Michel roots to three banana-parasitic nematodes. Ann. Appl. Biol. 124:65-73.

38. McSorley, R. 1994. The spiral nematode. Page 22 in: Compendium of Tropical Fruit Diseases. R. C. Ploetz, G. A. Zentmyer, W. T. Nishijima, K. G. Rohrbach, and H. D. Ohr, eds. American Phytopathological Society, St. Paul, MN.

39. O'Bannon, J. H. 1977. Worldwide dissemination of Radopholus similis and its importance in crop production. J. Nematol. 9:16-25.

40. Orton, K. J., and Siddiqi, M. R. 1973. Radopholus similis. CAB Descriptions of plantparasitic nematodes. Set 2, no. 27

41. Pattison, T., Stanton, J., and Lindsay, S. 1997. Burrowing nematode management. Inform. Ser. QI97034. Department of Primary Industries, Brisbane, Queensland.

42. Pinochet, J. 1992. Breeding bananas for resistance against lesion forming nematodes. Pages 157-169 in: Nematology from Molecule to Ecosystem. F. J. Gommers and P. W. T. Maas, eds. European Society of Nematologists, Inc., Scotland.

43. Price, N. S. 1995. The origin and development of banana and plantain cultivation Pages 1-13 in: Bananas and Plantains. S. R. Gowen, ed. Chapman \& Hall, London.

44. Razak, A. R. 1994. Plant-parasitic nematodes, a potential threat to commercial cultivation of banana in Malaysia. Pages 34-45 in: Banana Nematodes and Weevil Borers in Asia and the Pacific. R. V. Valmayor, R. G. Davide, J. M Stanton, N. L. Treverrow, and V. N. Roa, eds. INIBAP/APSNET, Philippines. 
45. Reynolds, P. K. 1927. The Banana: Its History, Cultivation and Place Among Staple Foods. Houghton Mifflin Co., Cambridge, MA. pp. 13-38.

46. Robinson, J. C. 1996. Bananas and Plantains. CAB International, Wallingford, Eng. pp. 1-2.

47. Rodríguez, D. W. 1955. Bananas: An outline of the economic history of production and trade with special reference to Jamaica. Department of Agriculture, Kingston, Jamaica. Commodity Bull. no. 1.

48. Rosengarten, F., Jr. 1995. Wilson Popenoe: Explorador Agrícola, Educador y Amigo de América Latina. Editorial Guaymuras. Tegucigalpa, Honduras. pp. 174-179.

49. Rowe, P. R., and Richardson, D. L. 1975. Breeding bananas for disease resistance, fruit quality and yield. Tropical Agriculture Research Services, La Lima, Honduras. Bull. no. 2.

50. Sarah, J. L., Sabatini, C., and Boisseau, M. 1993. Differences in pathogenicity to banana (Musa sp., cv. Poyo) among isolates of $R a-$ dopholus similis from different production areas of the world. Nematropica 23:75-79.

51. Sasser, J. N., and Freckman, D. W. 1987. A world perspective on nematology: The role of the society. Pages 7-14 in: Vistas on Nematology. J. A. Veech and D. W. Dickson, eds. Society of Nematologists, Inc., Hyattsville, MD.
52. Shaner, G., Stromberg, E. L., Lacy, G. H., Barker, K. R., and Pirone, T. P. 1992. Nomenclature and concepts of pathogenicity and virulence. Annu. Rev. Phytopathol. 30:47-66.

53. Sher, S. A. 1968. Revision of the genus $R a$ dopholus Thorne, 1949 (Nematoda: Tylenchoidea). Proc. Helminthol. Soc. Wash. 35:219-237.

54. Sikora, R. A., and Schlossen, E. 1973. Nematode and fungi associated with root systems of bananas in a state of decline in Lebanon. Plant Dis. Rep. 57:615-618.

55. Simmonds, N. W. 1959. Bananas. Longmans, Green \& Co., London. pp. 76-97, 308-333.

56. Simmonds, N. W. 1995. Bananas. Pages 370375 in: Evolution of Crop Plants. 2nd ed. J. Smart, and N. W. Simmonds, eds. Longman Scientific and Technical, Essex, Eng.

57. Simmonds, N. W., and Shepherd, K. 1955. The taxonomy and origins of cultivated bananas. J. Linn. Soc. Bot. 55:302-312.

58. Soto, M. 1992. Bananos: Cultivo y comercialización. 2da. ed. Litografía e Imprenta Lil, S.A., San José, Costa Rica.

59. Stephens, C. 1995. Banana Nematodes: Past, Present and Future. Pages 172-175 in: Memory of the First International Congress of Tropical Nematology.

60. Stover, R. H., and Simmonds, N. W. 1987. Bananas. 3rd ed. Longman Scientific \& Tech- nical, Essex, Eng.

61. Thorne, G. 1961. Principles of Nematology. McGraw-Hill Book Co., New York. pp. 226229.

62. United Fruit Company. 1929. The Story of the Banana. 5th ed. The Crosby Print, Boston.

63. United Fruit Company. 1958. Distribution of plant-parasitic nematodes and their importance in growth and production of bananas. United Fruit Co. Annu. Rep. pp. 54-58.

64. United Fruit Company. 1962. Varietal susceptibility to Radopholus similis. United Fruit Co. Annu. Rep. pp. iv, 73.

65. United Fruit Company. 1963. Valery planting program. United Fruit Co. Annu. Rep. p. 82

66. Van Sertima, I. 1976. They came before Columbus. Random House, New York. pp. 193 203.

67. Vavilov, N. I. 1949. The Origin, Variation, Immunity and Breeding of Cultivated Plants. Trans. K. Starr Chester, Waltham, Chronica Botanica.

68. Von Loesecke, H. W. 1950. Bananas. 2nd ed. Interscience Publishers, Inc., New York. pp. $1-15$.

69. Whitlock, L. S. 1957. The burrowing nematode found on ornamental banana plants at Baton Rouge, Louisiana. Plant Dis. Rep. 41(9). Mimeo.

70. Zhou, Z., and Xie, L. 1992. Status of banana diseases in China. Fruits 47:715-721. 